\title{
Professor Bent Sørensen
}

\author{
Henrik Marcussen, MD, DMSc
}

\author{
"Bent was a pioneer in the torture \\ rehabilitation movement and his word \\ and actions, through discrete, did so \\ much change - far more than most \\ people could conceive." \\ Sara Hamze, IRCT, Lebanon (citation from \\ "Words of condolence from the IRCT \\ family")
}

Bent Sørensen was born in 1924 in Fredericia on the east coast of Jutland in Denmark as the middle of three sons. His father was a Post Master and his mother a teacher. In 1942, his medical studies started in Århus and were partially undertaken during the German occupation.

Bent's practical training as a surgeon began immediately after his final medical exams in 1949. In 1961, with the title of Doctor of Medical Science under his belt and with solid surgical experience, he was ready to further his learning by gaining international experience. In the conflict that raged as a result of the Congo's independence movement against the Belgian's colonial rule, Bent got together with a handful of colleagues to take part in a Red Cross humanitarian expedition to the Congo to provide medical aid.

\section{Chief of Staff, Department of Plastic Surgery and Burns Unit}

When Bent finally finished his studies and became a surgeon of gastro-intestinal diseases, the relevant department at Kommunehospitalet, the illustrious old hospital in Copenhagen, had broadened its scope to include other types of medical issues including burns. Bent had experience from the department of plastic surgery that focused on treating cleft lips and palates. However, from 1965, he ended up having overall responsibility for burns as well. This circumstance can now of course be seen as setting a path to much of his later work. The Department of Plastic Surgery and Burns Unit was, from then on, the prominent treatment centre in Denmark for serious burns, which specifically involved treating patients' pain. In this regard, something so simple as water and more water became the key public message; thoughtfulness and simplicity often reap positive results, particularly when combined with researchbased achievements such as skin grafts, intensive antibacterial therapy and isolation of patients against the persistent infections often associated with these sort of injuries.

Knowledge that is now obvious was visionary thinking at that point in time. Bent's department moved to the newly opened hospital where a combination of modern buildings and thinking received international attention. This led to a great deal of travel in connection with educational programmes and teaching, and Bent became known by Danes as the burns expert who every year could be heard on the TV and radio warning against frivolous use of fireworks.

\section{Danish medical schools}

At the same time, Bent was elected to be a member of faculty at the medical school in Copenhagen after advocating for the creation of and implementation of medical schools. As Vice Dean and later Dean, he became a 
member of the leading department at Copenhagen University which was able to influence medical education and training. From 1973 to 1981, Bent was also a European member of the medical research in the EF, as it was called then. He was proud to see through the adoption of entry requirements and the theoretical and clinical training of both specialist doctors and general practitioners in the five years he was chairman. Throughout this work, it was Bent's firm belief that doctors should have a calling to work for the benefit of society and their fellow human beings, a topic which he later took up with respect to torture and human rights. This was exemplified at that time by Bent, as chairman, receiving the pledge that newly educated students took when they became fully-fledged doctors.

Bent was already equipped for the work that would follow, namely, the many years that he worked against torture and for human rights.

\section{RCT}

All this work came rather suddenly to an end when, in 1984, Bent accepted an offer from the Danish Medical Association (Den danske lægeorening (DADL)) to be chairman on the executive committee for the Rehabilitation Centre for Torture Victims, the RCT (now called DIGNITY ${ }^{\mathrm{i}}$ ). A short time before, in 1981, the RCT had been founded and was being run by Inge Genefke. The Chairman of DADL asked Bent to become chairman of the RCT's executive committee. A managerial and medical heavyweight was needed because of economic problems and differences of opinion on newly-utilised research methods. Bent had enjoyed a great deal of respect as Dean at the University and, through his

\footnotetext{
${ }^{\mathrm{i}}$ www.dignityinstitute.org/home/ ii www.irct.org
}

leadership of the Department of Plastic Surgery and Burns Unit, he had the experience that enabled him to create the necessary calm in order to deal with the funding which the then Ministry of Education suggested they would give to the relatively newly founded RCT in order to expand. Bent as chairman was complemented by medical and legal representatives and, happily, the much-needed funds became a reality and thereafter a fixed commitment in the Danish finance law for some time to come.

The work at the RCT started at this point to focus on how to treat those who had experienced torture and the necessary knowledge on torture's consequences, together with the potential to individualised treatment. Whereas the ability to treat physical injuries could be helped with the assistance of physiotherapy etc, psychological injuries proved to be more invasive. Assistance to help survivors get over torture developed, particularly with the introduction of social rehabilitation whilst recognizing the complicated position of being a refugee with language issues. At that time, the people who sought and obtained treatment were physically ruined and extremely badly affected psychologically. They were chiefly from Latin American countries, particularly Chile and Argentina. The new knowledge about torture's horrors gave a ghastly insight that could take hold of one and Bent became a tireless fighter for justice and providing assistance for this extremely vulnerable group.

\section{IRCT, CAT and CPT}

Meetings, training and, to an increasing degree, maintaining international connections, led to the founding of the RCT's international structure, the IRCT. ${ }^{\mathrm{ii}}$ It was an organization that would generate numerous future and many-facetted tasks to do with torture for both Bent and others. Additionally, 
it led to Bent's membership of the United Nations Committee against Torture (CAT) and, later, of the European Committee for the Prevention of Torture (CPT). Before his membership, these committees were made up of lawyers. He was able, as a doctor, to provide renewal and inspiration to the work. He became a travelling ambassador in the work against torture and not least in the coverage and control of the prisons that should be investigated in the 40 member states of the committee. In this capacity, Bent talked to prisoners, guards, inspected conditions, carried out reports and held governments to account in their duty to prevent and fight against torture. In addition, Bent was frequently sought after to give presentations and courses in many (often international) contexts, and these functions were often carried out in tandem with his wife Inge Genefke, founder of the RCT. Both have been honoured with numerous Danish and international prizes and honours. Bent was particularly happy that they both separately received the Danish Medical Association's Barfred Pedersen's prize of honour.

\section{Bent's later years}

Bent in his later years was chairman for the advisory committee for the Parker Institute at Frederiksberg Hospital in Copenhagen, founded by Alan and Jette Parker's OAK Foundation. Donations, not least from the Parker family out of respect for Bent and Inge's work, made the foundation of the Anti-Torture Support Foundation possible. ${ }^{\text {iii }}$ The foundation supports urgent work in the fight against torture and was a fund that Bent - until now - has taken an active role in. As a 'pensioner', Bent was often called in as an expert witness on cases concerning torture and was, together with 25 other concerned Danes, active in the legal charges against the Danish Prime Minister in 2003, arguing that the attacks in Iraq were against the constitution. In his articles 'The Supreme Court carried out a state coup' and 'The wall of silence', he argued in an in-depth and subtle way that, in going to war in Iraq, the government was not only trying to circumvent the Danish constitution, but also failing to uphold the treaties of the United Nations.

\section{Bent's character}

The memory of Bent Sørensen as a generous humanist, human rights activist and doctor will live for a long time to come. He was not just an immense intellect, with great medical skills and knowledge, he also had charm, empathy and vigour. Above all, he had an ability to get things done that was extraordinary.

Unlike the heavy subjects that employed him during his multi-facted work life, Bent had a harmonious life with many reasons to be happy. He was cheerful, sociable and charming - a brilliant host and a natural centre at a gathering. In spite of significant handicaps, such as a heart valve operation and the amputation of one leg, he was physically active up until a few months ago and even went swimming outside in the depths of winter. He was well-versed in music and literature and readily recited the odd citation.

At the commemoration on $14^{\text {th }}$ August at the Danish Medical Association in Copenhagen, many people attended, including earlier work colleagues, friends and torture survivors who had been treated under his care. Those who could not be there physically also made their presence felt; the IRCT presented a book which included many deeply felt words, memories and thanks from 76 members of the IRCT family. Many people had been personally touched by their relationship with Bent and wished to give him a final farewell.

\footnotetext{
iii http://www.atsf.dk
} 


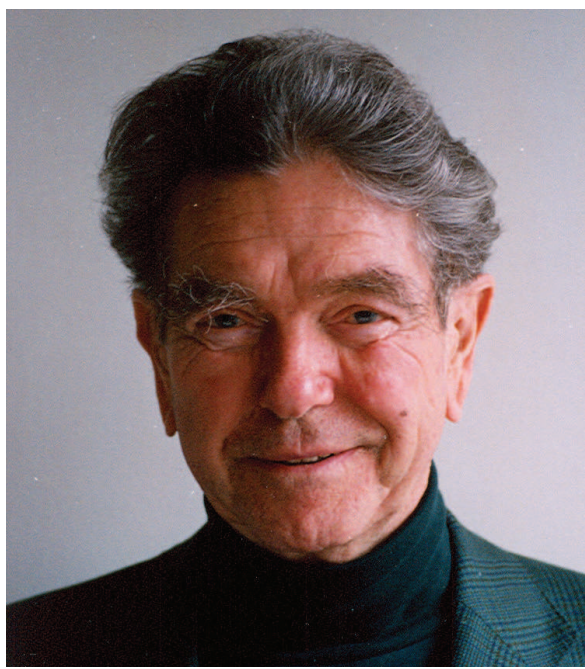

PROFESSOR BENT SØRENSEN, MD., DMSC. 8.3.1924-30.7.2017

Married physician Kirsten Ammentorp (1949-1989)

Married Inge Genefke 1991, MD, DMSc. h.c. mult., founder of RCT (1982) and IRCT (1985).

\section{Education:}

MD: $\quad 1949$

DMSc.: 1958

Top Positions within the Danish Medical Health System:

Chief of Staff, Department of Plastic Surgery and Burns Unit, University of Copenhagen, 1965-90.

Administrative work - national:

Member of the board of the Medical

Faculty of the University of Copenhagen, Vice-dean, 1972-73, \& Dean, 1974-75.

Vice-Chairman and Chairman of the Advisory Board on Health Education to the Minister of Education (FLUSU), 1975-81. Member and manager of the board of the
Anti-torture Support Foundation (ATSF) 2002-2017.

Administrative work - international: Commission of the European Communities in 1973 in order to survey the Directives concerning the free movement of doctors. Member of this committee from its start in 1976-83.

Rehabilitation and torture work:

Chairman of the Board, RCT from 1984 to 1990 .

Member of the IRCT Council, 1990-1995. Member of United Nations Committee against Torture (CAT), 1988 - 1990. Vice-Chairman of the Committee, re-elected 1998, Rapporteur to the Committee until 2000.

Member of the European Council Committee for the Prevention of Torture (CPT), September 1989-1997, Vice-President of the Committee, 1989-1995.

Senior Medical Adviser to the IRCT for many years.

National and International Teaching:

Training Courses on Torture and Medical Ethics.

Raoul Wallenberg Institute and Danish Institute for Human Rights: Lectures.

Report writing:

Adviser to the governments of Zambia, Kenya and Nepal on report writing to the UN Committee against Torture.

\section{Honours:}

12 Honorary memberships - national, European and other international.

Order:

Knight of the Dannebrog, 1978, of the First Grade, 1990. 